\title{
Effect on Yield and Benefit Cost Ratio of Green gram at Different Phosphorus Levels and Frequency of Boron Levels
}

\author{
Preeti Choudhary*, Gautam Ghosh, Neha and Shobha Kumari
}

Department of Agronomy, Sam Higginbottom Institute of Agriculture, Technology and Sciences, (Formerly Allahabad Agricultural Institute), (Deemed to-be-University), Allahabad - 211007 (U.P), India

*Corresponding author

\section{A B S T R A C T}

\begin{tabular}{|c|}
\hline Keywords \\
\hline $\begin{array}{l}\text { Mung bean, } \\
\text { Phosphorus levels, } \\
\text { Boron frequency, } \\
\text { Grain and Straw } \\
\text { yield and Benefit } \\
\text { Cost Ratio. }\end{array}$ \\
\hline Article Info \\
\hline $\begin{array}{l}\text { Accepted: } \\
17 \text { May } 2017 \\
\text { Available Online: } \\
\text { 10 June } 2017\end{array}$ \\
\hline
\end{tabular}

A field experiment was conducted during Zaid season, 2015 at the Crop Research Farm, Department of Agronomy, SHIATS, Allahabad (U.P.) to concluded the response of different phosphorus levels and frequency of boron levels on growth and yield of summer Greengram (Vigna radiata L.) in Randomized Block Design with twelve treatments replicated thrice. Among the different phosphorus levels and frequency of boron levels under in treatment T11 i.e., N3 (20:60:20 NPK) + $0.2 \%$ foliar spray of borax at 35DAS (pre-flowering) recorded maximum grain yield $\left(1.62 \mathrm{t} \mathrm{ha}^{-1}\right)$, straw yield $\left(2.85 \mathrm{t} \mathrm{ha}^{-1}\right)$, protein content $(24.56 \%)$ and harvest index $(36.15 \%)$, whereas the lowest value $0.99 \mathrm{t} \mathrm{ha}^{-1}, 2.06 \mathrm{t} \mathrm{ha}^{-1}, 20.36 \%$ and $32.58 \%$ respectively) in the treatment T1 i.e., N1 (20:40:20 NPK). The highest gross return $\left(78795.00 \mathrm{ha}^{-1}\right)$, net return $\left(57222.00 \mathrm{ha}^{-1}\right)$ and benefit cost ratio (2.65) were registered in treatment T11 i.e., N3 (20:60:20NPK) $+0.2 \%$ foliar spray of borax at 35DAS (pre-flowering). Whereas the lowest value $\left(48925.50 \mathrm{ha}^{-1}\right)$, (30075.50 ha-1) and (1.59) respectively in the treatment T1 i.e. N1 (20:40:20 NPK).

\section{Introduction}

Pulses are the main source of protein particularly for vegetarian and contribute about 14 per cent of the total protein of average Indian diet. The per capita availability in pulses dwindling fast from 35.0 g/capita per day in 2005 as against the minimum requirement of $84 \mathrm{~g}$ per day per capita prescribed by ICMR, which is causing malnutrition among the growing people (Anonymous, 2005-06). Pulse production is very low and become challenging problem against the requirement of increasing population of our country. It has the capacity to fix atmospheric nitrogen. It's one of the important kharif pulse crops of India which can be grown as catch crop between rabi and kharif -seasons. India alone accounts for $65 \%$ of its world acreage and 54\% of the total production. It is grown on about 3.50 mha in the country mainly in Rajasthan, Maharashtra, Andhra Pradesh, Karnataka, Orissa and Bihar. Mung bean is an excellent source of protein (25\%) with high quality of lysine $(460 \mathrm{mg} / \mathrm{g})$ and tryptophan $(60 \mathrm{mg} / \mathrm{g})$. The total area 
under pulses is 23.63 mha with an annual production of $14.76 \mathrm{M}$ tonnes in the country. In India green gram occupies 3.4 million hectare area and contributes to 1.4 million tonnes in pulse production (Anonymous, 2010-11). Mung bean contributes $14 \%$ in total pulse area and $7 \%$ in total pulse production in India. The low productivity of mung bean may be due to nutritional deficiency in soil and imbalanced external fertilization (Awomi et al., 2012). It is mostly grown under dry land farming system where erratic rains often fetch the crop under moisture stress (Malik et al., 2006). Nitrogen requirement of pulse crops is very low than other crops because nitrogen needed only for establishment of plant after that plants fulfill their requirement through symbiotic nitrogen fixation. Phosphorus is an important plant nutrient for greengram. Indian soils are poor to medium in available phosphorus. Only about 30 per cent of the applied phosphorus is available for crops and remaining part converted into insoluble phosphorus (Sharma and Khurana, 1997). As the concentration of available $P$ in the soil solution is normally insufficient to support the plant growth, continual replacement of soluble $\mathrm{P}$ from inorganic and organic sources is necessary to meet the $\mathrm{P}$ requirements of crop (Tisdale et al., 2010).

Additional application of $\mathrm{P}$ is Increase nodule formation which increases nitrogen fixation and finally productivity of greengram (Prasad et al., 2014). Nitrogen and phosphorus alone or in combination play a remarkable role in increasing yield and improving the quality of mung bean. Phosphorus deficiency can limit nodulation by legumes and $\mathrm{P}$ fertilizer application can overcome the deficiency (Carsky et al., 2001). Efficiency of P fertilizer throughout the world is around $10-25 \%$ (Isherword, 1998). Among the various factors responsible for maximizing the yield of greengram, phosphorus levels and frequency of boron levels is most important. It is essential that greengram should not suffer due to inadequate mineral especially phosphorus. It is necessary to use them economically in combination with phosphorus and boron, as greengram shows high response to high phosphorus levels and frequency of boron levels.

\section{Materials and Methods}

Field experiment was conducted during Zaid season 2015 at Crop Research Farm, Sam Higginbottom Institute of Agriculture, Technology and Sciences (Deemed-to-beUniversity) Allahabad. The experimental site is located at $25057 \mathrm{~N}$ latitude, $87019 \mathrm{E}$ longitude and at an altitude of above mean sea level. The soil of the experimental area was sandy loam with moderately alkaline $\mathrm{pH}$; low in organic carbon $(0.32 \%)$ and available $\mathrm{N}$ (188.30 kg ha $\left.{ }^{-1}\right)$, available $\mathrm{P}\left(34.50 \mathrm{~kg} \mathrm{ha}^{-1}\right)$ and available $\mathrm{K}\left(87.00 \mathrm{~kg} \mathrm{ha}^{-1}\right)$ during zaid 2015 respectively. A recommended greengram variety (SAMRAT) was chosen for the study. The experiment was laid out in Randomized Block Design (RBD) with two factor different levels of phosphorus [20:50:20 kg ha ${ }^{-1}, 20: 60: 20 \mathrm{~kg} \mathrm{ha}^{-1}$ (P3)] and frequency levels of boron [no application, 20 and 35 DAS, $0.2 \%$ foliar spray of borax] with twelve treatments combination on a plot size of $3 \times 3 \mathrm{~m}^{2}$. Before sowing, line were formed in the field as the spacing in treatments. Mungbean was sown in line and covered with the soil. Mungbean seeds were hand dibbled. The total quantity of nitrogen, phosphorus and potassium as per treatment in the form of Urea (46\%), single super phosphate (16\%) and MOP (60\%) respectively were applied below the seeds at the time of sowing and $0.2 \%$ solution of borax was prepared and sprayed at 20 and 35 DAS. All the agronomic practices were carried out uniformly to raised the crop. For taking data on yield and yield components on mungbean five plants were selected randomly in each plot. 


\section{Economics analysis}

Cost of cultivation, gross return, net return and benefit cost ratio was worked out to evaluate the economics of each treatment, based on the existing market prices of inputs and output.

\section{Cost of Cultivation $\left(\mathrm{ha}^{-1}\right)$}

The cost of cultivation for each treatment was work out separately, taking into consideration all the cultural practices followed and costs of inputs used in the cultivation.

\section{Gross return $\left(h^{-1}\right)$}

The gross return from each treatment was calculated

Gross return $\left(\mathrm{ha}^{-1}\right)=$ Income from grain + income from stover

\section{Net return $\left(h^{-1}\right)$}

The net profit from each treatment was calculated separately, by using the following formula

Net return $=$ Gross return $\left(\mathrm{ha}^{-1}\right)-$ Cost of cultivation $\left(\mathrm{ha}^{-1}\right)$

\section{Benefit cost ratio}

The benefit cost ratio was calculated using the following formula

$$
\text { Benefit cost ratio }=\frac{\text { Gross return }\left(\mathrm{ha}^{-1}\right)}{\text { Total cost of cultivation }\left(\mathrm{ha}^{-1}\right)}
$$

\section{Results and Discussion}

\section{Grain yield}

Grain yield differed significantly due to boron application. The highest grain yield $\left(2.85 \mathrm{tha}^{-1}\right)$ was found in T11 N3 (20:60:20 NPK) + 35
DAS (0.2\% foliar spray of boron) application (Table 1). Boron application significantly increased the seed yield Mondal et al., (2003). Boron has significant effect on seed yield. Highest seed yield $\left(2.85 \mathrm{tha}^{-1}\right)$ was found in T11 N3 (20:60:20 NPK) + 35 DAS (0.2\% foliar spray of boron) application. The minimum yield was found with no boron application that is T1 N1 (20:40:20 NPK) alone. These results are almost similar to Saha et al., (1996) and Yakardi et al., (2002).

\section{Biological yield}

Foliar spray of boron showed that, there is non-significant effect among the treatments on biological yield of mungbean. Highest biological yield $\left(2.85 \mathrm{t} \mathrm{ha}^{-1}\right)$ was found with T11 N3 (20:60:20 NPK) + 35 DAS (0.2\% foliar spray of boron) application. Increase in biological yield may be due to foliar spray of boron, which significantly enhances straw and grain yield in mungbean. Boron showed significantly maximum biological yield (2.06 $\mathrm{t} \mathrm{ha}^{-1}$ ) with no application of boron that is $\mathrm{T} 1$ N1 (20:40:20) alone. These results are in line with Luikham et al., (2005), Kaisher et al., (2010) and Rathour et al., (2015).

\section{Economics of treatment}

Observations regarding the response of different levels of phosphorus and frequency of boron levels on economics of greengram are given in table 1 to 4 .

\section{Cost of cultivation}

Maximum cost of cultivation (22962.00 ha $\left.{ }^{-1}\right)$ was recorded in treatment $\mathrm{T} 12$ i.e., $\mathrm{N} 3$ $(20: 60: 20 \mathrm{NPK})+20$ and 35DAS $(0.2 \%$ foliar spray of borax), whereas the lowest value $\left(18850.00 \mathrm{ha}^{-1}\right)$ was observed in treatment T1 i.e., N1 (20:40:20 NPK). According to Ali et al., (2002) and Suman et al., (2007) production value are increased the application of NPK. 


\section{Gross return}

Maximum gross return (78795.00 $\left.\mathrm{ha}^{-1}\right)$ was recorded in treatment T11 i.e., N3 (20:60:20 $\mathrm{NPK})+(0.2 \%$ foliar spray of borax $)$ at 35 DAS, which was the lowest value (48925.00 $\mathrm{ha}^{-1}$ ) was observed in treatment $\mathrm{T} 1$ i.e., N1 (20:40:20 NPK). Gupta et al., (2007), Narendra et al., (2009) and Rathi et al., (2009) also observed similar finding.

Net return

Maximum net return (57222.00 $\left.\mathrm{ha}^{-1}\right)$ was recorded in treatment T11 i.e. N3 (20:60:20 $\mathrm{NPK})+(0.2 \%$ foliar spray of borax $)$ at 35 DAS, whereas the lowest value (30075.50 ha-1) was observed in treatment $\mathrm{T} 1$ i.e., $\mathrm{N} 1$ (20:40:20 NPK). The results are in conformity with those of, Giller and Cadisch (1995), Ganeshamurthy et al., (2005) and Dixit and Elamathi (2007). Benefit cost ratio: Maximum benefit cost ratio (2:65) was recorded in treatment T11 i.e. N3 (20:60:20 $\mathrm{NPK})+(0.2 \%$ foliar spray of borax $)$ at 35 DAS, whereas the lowest value 1:59 was observed in treatment T1 i.e. N1 (20:40:20 NPK). The results are in conformity with those of Hussain et al., (1996) and Jena et al., (2009). The probable reason for increase in economics of treatment T11 i.e., N3 (20:60:20 $\mathrm{NPK})+(0.2 \%$ foliar spray of borax $)$ at 35 DAS, due to high level of $\mathrm{P}+0.2 \%$ foliar spray of borax at 35DAS (pre flowering) through application of SSP and borax recorded higher net returns, $\mathrm{B}: \mathrm{C}$ ratio, protein content, $\mathrm{N}$ and $\mathrm{P}$ uptake and available phosphorus in soil in field pea than that of DAP and AMF are in the findings of Singh et al., (2005).

\section{Soil fertility status}

Observations regarding the response of different levels of phosphorus and frequency of boron levels on soil fertility status after harvest of greengram are given in table 5. A perusal of the table reveals that there was a steady increase in the soil fertility status after harvesting of greengram.

Table.1 Cost of cultivation (for Agro practices) of per common cost of Cultivation fixed cost of all treatment

\begin{tabular}{|c|c|c|c|c|c|c|}
\hline & SI. No. & Particulars & Unit & Qty. & Rate/Unit(₹) & $\operatorname{Cost}\left(₹ h^{-1}\right)$ \\
\hline A. & & Land preparation & & & & \\
\hline & 1 & Ploughing & Hours & $3 \mathrm{hr}$ & 300 & 900.00 \\
\hline & 2 & Disc harrowing & Hours & $3 \mathrm{hr}$ & 250 & 750.00 \\
\hline & 3 & Leveling & Hours & $4 \mathrm{hr}$ & 200 & 800.00 \\
\hline & 4 & Lay out of the field & Labour & 8 & 100 & 800.00 \\
\hline B. & & Seed sowing & & & & \\
\hline & 1 & Seed & Rate & $20 \mathrm{~kg} \mathrm{ha}^{-1}$ & 150 & 3000.00 \\
\hline & 2 & Sowing & Labour & 4 & 100 & 400.00 \\
\hline C. & & Fertilizer & & & & \\
\hline & 1 & Urea & Charges & $47 \mathrm{~kg} \mathrm{ha}^{-1}$ & 10 & 470.00 \\
\hline & 2 & MOP & Charges & $34 \mathrm{~kg} \mathrm{ha}^{-1}$ & 20 & 680.00 \\
\hline D. & & Irrigation & & & & \\
\hline & 1 & Irrigation & Number & 3 & 800 & 2400.00 \\
\hline & 2 & Labour & Charges & 6 & 100 & 600.00 \\
\hline E. & & Harvesting & & & & \\
\hline & 1 & Harvesting & Labour & 15 & 100 & 1500.00 \\
\hline & 2 & Threshing & Labour & 8 & 100 & 800.00 \\
\hline & 3 & Winnowing & Labour & 6 & 100 & 600.00 \\
\hline F. & & Depreciation & & & & \\
\hline G. & & Reatal value of land & Months & 3 & 750 & 2250.00 \\
\hline H. & & Supervision charges & Months & 3 & 300 & 900.00 \\
\hline & & & & $\begin{array}{l}\text { Total cost of } \\
\text { cultivation }\left(₹ \mathrm{ha}^{-1}\right)\end{array}$ & & 16850.00 \\
\hline
\end{tabular}


Table.2 Variable cost and cost of cultivation on each treatment

\begin{tabular}{|c|c|c|c|c|c|c|}
\hline & Treatments & $\begin{array}{l}\text { Fixed cost } \\
\left(₹ \mathbf{h a}^{-1}\right)\end{array}$ & $\begin{array}{l}\text { Cost of SSP } \\
\left(₹ \mathrm{ha}^{-1}\right)\end{array}$ & $\begin{array}{l}\text { Cost of boron } \\
\left(₹ h^{-1}\right)\end{array}$ & $\begin{array}{l}\text { Variable cost } \\
\left(₹^{\left(₹ a^{-1}\right)}\right.\end{array}$ & $\begin{array}{l}\text { Total cost } \\
\left(₹ \text { ha }^{-1}\right)\end{array}$ \\
\hline $\mathrm{T}_{1}$ & $\mathrm{~N}_{1}(20: 40: 20 \mathrm{NPK})$ & 16850.00 & 2000.00 & - & 2000.00 & 18850.00 \\
\hline $\mathrm{T}_{2}$ & $\begin{array}{l}\mathrm{N}_{2}(20: 40: 20 \mathrm{NPK})+20 \mathrm{DAS} \\
(0.2 \% \mathrm{FsB})\end{array}$ & 16850.00 & 2000.00 & 1389.00 & 3389.00 & 20239.00 \\
\hline $\mathrm{T}_{3}$ & $\begin{array}{l}\mathrm{N}_{1}(20: 40: 20 \quad \mathrm{NPK})+35 \mathrm{DAS} \\
(0.2 \% \text { FsB })\end{array}$ & 16850.00 & 2000.00 & 1389.00 & 3389.00 & 20239.00 \\
\hline $\mathrm{T}_{4}$ & $\begin{array}{l}\mathrm{N}_{1}(20: 40: 20 \mathrm{NPK})+20 \& 35 \mathrm{D} \\
\mathrm{AS}(0.2 \% \mathrm{FsB})\end{array}$ & 16850.00 & 2000.00 & 2778.00 & 4778.00 & 21628.00 \\
\hline $\mathrm{T}_{5}$ & $\mathrm{~N}_{2}(20: 50: 20 \mathrm{NPK})$ & 16850.00 & 2500.00 & - & 2500.00 & 19350.00 \\
\hline $\mathrm{T}_{6}$ & $\begin{array}{l}\mathrm{N}_{2}(20: 50: 20 \mathrm{NPK})+20 \text { DAS } \\
(0.2 \% \text { FsB })\end{array}$ & 16850.00 & 2500.00 & 1389.00 & 3889.00 & 20739.00 \\
\hline $\mathrm{T}_{7}$ & $\begin{array}{l}\mathrm{N}_{2}(20: 50: 20 \mathrm{NPK})+35 \mathrm{DAS} \\
(0.2 \% \text { FsB })\end{array}$ & 16850.00 & 2500.00 & 1389.00 & 3889.00 & 20739.00 \\
\hline $\mathrm{T}_{8}$ & $\begin{array}{l}\mathrm{N}_{2}(20: 50: 20 \mathrm{NPK})+20 \& 35 \mathrm{D} \\
\mathrm{AS}(0.2 \% \text { FsB })\end{array}$ & 16850.00 & 2500.00 & 2778.00 & 5278.00 & 22128.00 \\
\hline $\mathrm{T}_{9}$ & $\mathrm{~N}_{3}(20: 60: 20 \mathrm{NPK})$ & 16850.00 & 3334.00 & - & 3334.00 & 20184.00 \\
\hline $\mathrm{T}_{10}$ & $\begin{array}{l}\mathrm{N}_{3}(20: 60: 20 \mathrm{NPK})+20 \mathrm{DAS} \\
(0.2 \% \mathrm{FsB})\end{array}$ & 16850.00 & 3334.00 & 1389.00 & 4723.00 & 21573.00 \\
\hline $\mathrm{T}_{11}$ & $\begin{array}{l}\mathrm{N}_{3}(20: 60: 20 \mathrm{NPK})+35 \mathrm{DAS} \\
(0.2 \% \mathrm{FsB})\end{array}$ & 16850.00 & 3334.00 & 1389.00 & 4723.00 & 21573.00 \\
\hline $\mathrm{T}_{12}$ & $\begin{array}{l}\mathrm{N}_{3}(20: 60: 20 \mathrm{NPK})+20 \& 35 \mathrm{D} \\
\mathrm{AS}(0.2 \% \mathrm{FsB})\end{array}$ & 16850.00 & 3334.00 & 2778.00 & 6112.00 & 22962.00 \\
\hline & $\begin{array}{l}\text { Urea }=10 ₹ \mathrm{~kg}^{-1}, \mathrm{SSP}=8 ₹ \mathrm{~kg}^{-} \\
{ }^{-} \\
\text {MOP }=20 ₹ \mathrm{~kg}^{-1}, \text { Boron }=50 ₹ \\
100 \mathrm{~g}^{-1}\end{array}$ & & & & & \\
\hline
\end{tabular}

FsB -Foliar spray of Boron

Table.3 Mean grain yield and straw yield grain and straw return and gross return

\begin{tabular}{|c|c|c|c|c|c|c|}
\hline & Treatments & Yield $\left(\mathrm{t} \mathrm{ha}^{-1}\right)$ & & Return $(₹$ & & Gross return \\
\hline & & Grain yield & Straw yield & Grain & Straw & \\
\hline $\mathrm{T}_{1}$ & $\mathrm{~N}_{1}(20: 40: 20 \mathrm{NPK})$ & 0.99 & 2.06 & 45816.00 & 3109.50 & 48925.50 \\
\hline $\mathrm{T}_{2}$ & $\mathrm{~N}_{2}(20: 40: 20 \mathrm{NPK})+20 \mathrm{DAS}(0.2 \% \mathrm{FsB})$ & 1.12 & 2.28 & 51566.00 & 3429.00 & 54995.00 \\
\hline $\mathrm{T}_{3}$ & $\mathrm{~N}_{1}(20: 40: 20 \mathrm{NPK})+35 \mathrm{DAS}(0.2 \% \mathrm{FsB})$ & 1.22 & 2.33 & 56120.00 & 3499.50 & 59619.50 \\
\hline $\mathrm{T}_{4}$ & $\mathrm{~N}_{1}(20: 40: 20 \mathrm{NPK})+20 \& 35 \mathrm{DAS}(0.2 \% \mathrm{FsB})$ & 1.28 & 2.38 & 58880.00 & 3579.00 & 62459.00 \\
\hline $\mathrm{T}_{5}$ & $\mathrm{~N}_{2}(20: 50: 20 \mathrm{NPK})$ & 1.22 & 2.33 & 56120.00 & 3499.50 & 59619.50 \\
\hline $\mathrm{T}_{6}$ & $\mathrm{~N}_{2}(20: 50: 20 \mathrm{NPK})+20 \mathrm{DAS}(0.2 \% \mathrm{FsB})$ & 1.34 & 2.46 & 61778.00 & 3699.00 & 65477.00 \\
\hline $\mathrm{T}_{7}$ & $\mathrm{~N}_{2}(20: 50: 20 \mathrm{NPK})+35 \mathrm{DAS}(0.2 \% \mathrm{FsB})$ & 1.36 & 2.67 & 62836.00 & 4009.50 & 66845.50 \\
\hline $\mathrm{T}_{8}$ & $\mathrm{~N}_{2}(20: 50: 20 \mathrm{NPK})+20 \& 35 \mathrm{DAS}(0.2 \% \mathrm{FsB})$ & 1.33 & 2.67 & 61180.00 & 4009.50 & 65189.50 \\
\hline $\mathrm{T}_{9}$ & $\mathrm{~N}_{3}(20: 60: 20 \mathrm{NPK})$ & 1.24 & 2.43 & 57316.00 & 3645.00 & 60961.00 \\
\hline $\mathrm{T}_{10}$ & $\mathrm{~N}_{3}(20: 60: 20 \mathrm{NPK})+20 \mathrm{DAS}(0.2 \% \mathrm{FsB})$ & 1.35 & 2.48 & 62238.00 & 3729.00 & 65967.00 \\
\hline $\mathrm{T}_{11}$ & $\mathrm{~N}_{3}(20: 60: 20 \mathrm{NPK})+35 \mathrm{DAS}(0.2 \% \mathrm{FsB})$ & 1.62 & 2.85 & 74520.00 & 4275.00 & 78795.00 \\
\hline $\mathrm{T}_{12}$ & $\mathrm{~N}_{3}(20: 60: 20 \mathrm{NPK})+20 \& 35 \mathrm{DAS}(0.2 \% \mathrm{FsB})$ & 1.40 & 2.69 & 64400.00 & 4039.50 & 68439.50 \\
\hline & $\begin{array}{l}\text { Sale rate of grain }=46 ₹ \mathrm{~kg}^{-1} \\
\text { Sale rate of straw }=1.5 ₹ \mathrm{~kg}^{-1}\end{array}$ & & & & & \\
\hline
\end{tabular}

FsB -Foliar spray of Boron 
Table.4 Total cost of cultivation $\left(₹ \mathrm{ha}^{-1}\right)$ gross return $\left(₹ \mathrm{ha}^{-1}\right)$ net return $\left(₹ \mathrm{ha}^{-1}\right.$ ) and benefit cost ratio

\begin{tabular}{llllll}
\hline & Treatments & $\begin{array}{l}\text { Cost of } \\
\text { cultivation } \\
\left(₹ \text { ha }^{-1}\right)\end{array}$ & $\begin{array}{l}\text { Gross } \\
\text { return } \\
\left(₹ \text { ha }^{-1}\right)\end{array}$ & $\begin{array}{l}\text { Net return }_{\left(₹ \mathbf{h a}^{-1}\right)} \\
\mathrm{T}_{1}\end{array}$ & $\begin{array}{l}\text { Benefit cost } \\
\text { ratio }\end{array}$ \\
$\mathrm{T}_{2}$ & $\mathrm{~N}_{1}(20: 40: 20 \mathrm{NPK})$ & 18850.00 & 48925.50 & 30075.50 & 1.59 \\
$\mathrm{~T}_{3}$ & $\mathrm{~N}_{1}(20: 40: 20 \mathrm{NPK})+20 \mathrm{DAS}(0.2 \% \mathrm{FsB})$ & 20239.00 & 54995.00 & 34756.00 & 1.71 \\
$\mathrm{~T}_{4}$ & $\mathrm{~N}_{1}(20: 40: 20 \mathrm{NPK})+35 \mathrm{DAS}(0.2 \% \mathrm{FsB})$ & 20239.00 & 59619.50 & 39380.50 & 1.94 \\
$\mathrm{~T}_{5}$ & $\mathrm{~N}_{2}(20: 50: 20 \mathrm{NPK})$ & 21628.00 & 62459.00 & 40831.00 & 1.88 \\
$\mathrm{~T}_{6}$ & $\mathrm{~N}_{2}(20: 50: 20 \mathrm{NPK})+20 \mathrm{DAS}(0.2 \% \mathrm{FsB})$ & 20739.00 & 65477.00 & 44738.00 & 2.15 \\
$\mathrm{~T}_{7}$ & $\mathrm{~N}_{2}(20: 50: 20 \mathrm{NPK})+35 \mathrm{DAS}(0.2 \% \mathrm{FsB})$ & 20739.00 & 66845.50 & 46106.50 & 2.22 \\
$\mathrm{~T}_{8}$ & $\mathrm{~N}_{2}(20: 50: 20 \mathrm{NPK})+20 \& 35 \mathrm{DAS}(0.2 \% \mathrm{FsB})$ & 22128.00 & 65189.50 & 43061.50 & 1.94 \\
$\mathrm{~T}_{9}$ & $\mathrm{~N}_{3}(20: 60: 20 \mathrm{NPK})$ & 20184.00 & 60961.00 & 40777.00 & 2.08 \\
$\mathrm{~T}_{10}$ & $\mathrm{~N}_{3}(20: 60: 20 \mathrm{NPK})+20 \mathrm{DAS}(0.2 \% \mathrm{FsB})$ & 21573.00 & 65967.00 & 44394.00 & 2.08 \\
$\mathrm{~T}_{11}$ & $\mathrm{~N}_{3}(20: 60: 20 \mathrm{NPK})+35 \mathrm{DAS}(0.2 \% \mathrm{FsB})$ & 21573.00 & 78795.00 & 57222.00 & 2.65 \\
$\mathrm{~T}_{12}$ & $\mathrm{~N}_{3}(20: 60: 20 \mathrm{NPK})+20 \& 35 \mathrm{DAS}(0.2 \% \mathrm{FsB})$ & 22962.00 & 68439.50 & 45477.50 & 1.98 \\
\hline
\end{tabular}

FsB -Foliar spray of Boron

Table.5 Effect of phosphorus levels and frequency of Boron levels on Soil fertility status after harvest of Green gram

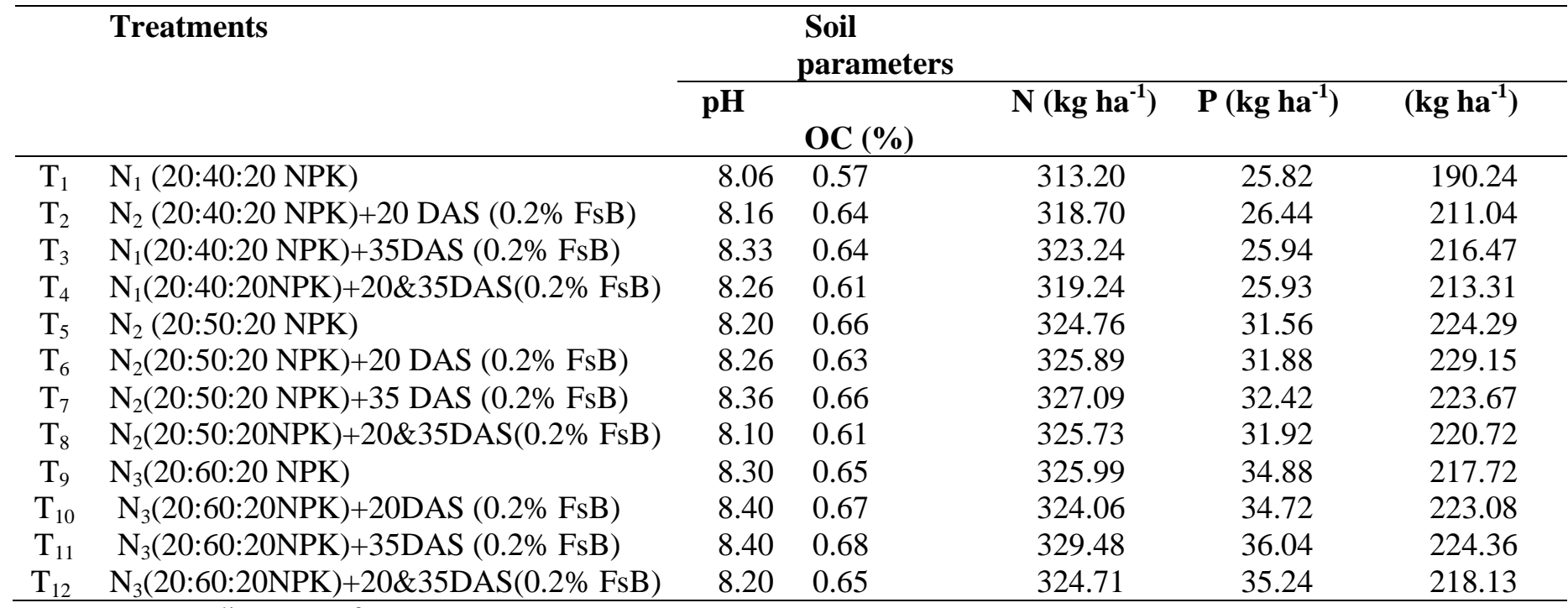

FsB -Foliar spray of Boron

$\mathbf{P}_{2} \mathbf{O}_{5}$

Maximum available P2O5 (36.04kg ha $\left.{ }^{-1}\right)$ was obtained by the application of T11 i.e. N3 $(20: 60: 20 \mathrm{NPK})+(0.2 \%$ foliar spray of borax) at 35 DAS, whereas the lowest value $25.82 \mathrm{~kg} \mathrm{ha}^{-1}$ was observed in treatments $\mathrm{T} 1$ i.e. N1 (20:40:20 NPK).
$\mathbf{N}$

Maximum available $\mathrm{N}\left(329.48 \mathrm{~kg} \mathrm{ha}^{-1}\right)$ was obtained by the application of $\mathrm{T} 11$ i.e. $\mathrm{N} 3$ $(20: 60: 20 \mathrm{NPK})+(0.2 \%$ foliar spray of borax) at $35 \mathrm{DAS}$, the lowest value $313.20 \mathrm{~kg}$ $\mathrm{ha}^{-1}$ was observed in treatments $\mathrm{T} 1$ i.e. $\mathrm{N} 1$ (20:40:20 NPK). 


\section{$\mathrm{K}_{2} \mathrm{O}$}

Maximum available $\mathrm{K}_{2} \mathrm{O}\left(224.36 \mathrm{~kg} \mathrm{ha}^{-1}\right)$ was obtained by the application of T11 i.e. N3 $(20: 60: 20 \mathrm{NPK})+(0.2 \%$ foliar spray of borax) at 35 DAS, whereas the lowest value $190.24 \mathrm{~kg} \mathrm{ha}^{-1}$ was observed in treatments T1 i.e. N1 (20:40:20 NPK).

\section{$\mathrm{OC}(\%)$}

Maximum Organic carbon (0.68\%) was obtained by the application of T11 i.e. N3 $(20: 60: 20 \mathrm{NPK})+(0.2 \%$ foliar spray of borax) at 35 DAS, whereas the lowest value $0.58 \%$ in T1 i.e. N1 (20:40:20 NPK).

\section{pH}

Maximum $\mathrm{pH} 8.4$ was obtained by the application of T11 i.e. N3 (20:60:20 NPK) + (0.2\% foliar spray of borax) at 35 DAS, whereas the lowest value 8.0 was observed in treatments T1 i.e. N1 (20:40:20 NPK).

Probable reason for increase in soil fertility status after harvest of T11 i.e. N3 (20:60:20 $\mathrm{NPK})+(0.2 \%$ foliar spray of borax $)$ at 35 DAS, due to soil improved the nutritional status, soil physico-chemical properties and soil microbial population which resulted in increased availability of these elements and SSP provided the phosphorus with $\mathrm{Ca}$ and sulphur, resulted into their higher uptake by the crop. Uptake of N, P and $\mathrm{K}$ is a function of the content of these elements in seed and straw and their respective yields. Thus increase in content of these elements in seeds and straw and significant increase in yields have been resulted due to increased uptake of $\mathrm{N}, \mathrm{P}$, and $\mathrm{K}$ by the crop. It has also improved the soil physical conditions which in turn improved the nutrient uptake and hence content increased. Similar results were also reposted by Basak and Subodh (2002), Hemalatha et al., (2002) and Kumar et al., (2002).
Phosphorus application might have resulted in root proliferation and increased density of root nodules, which in turn resulted in higher microbial activities in the root and hence better availability of $\mathrm{N}$ and $\mathrm{P}$ to plant occurred. This increased uptake of nutrient manifested in increased growth. Similar finding was reported by Trivedi (1996), Singh and Tripathi (2005), Havarasi et al., (2007), and Singh et al., (2012).

Among the different phosphorus levels and frequency of boron levels under in treatment T11 i.e., $\mathrm{N} 3(20: 60: 20 \mathrm{NPK})+0.2 \%$ foliar spray of borax at 35DAS (pre-flowering) recorded maximum grain yield $\left(1.62 \mathrm{t} \mathrm{ha}^{-1}\right)$ and straw yield $\left(2.85 \mathrm{t} \mathrm{ha}^{-1}\right)$, whereas the lowest value $\left(0.99 \mathrm{t} \mathrm{ha}^{-1}\right.$ and $2.06 \mathrm{t} \mathrm{ha}^{-1}$ respectively) in the treatment $\mathrm{T} 1$ i.e., $\mathrm{N} 1$ (20:40:20 NPK). The highest gross return $\left(78795.00 \mathrm{ha}^{-1}\right)$, net return $\left(57222.00 \mathrm{ha}^{-1}\right)$ and benefit cost ratio (2.65) were registered in treatment T11 i.e., $\mathrm{N} 3$ (20:60:20NPK) + 0.2\% foliar spray of borax at 35DAS (preflowering). Whereas the lowest value $\left(48925.50 \mathrm{ha}^{-1}\right),\left(30075.50 \mathrm{ha}^{-1}\right)$ and (1.59) respectively in the treatment $\mathrm{T} 1$ i.e., $\mathrm{N} 1$ (20:40:20 NPK).

\section{References}

Ali, A., M.A. Chaudhry, M.A. Siddique, Saifullah and M.N. Akram. 2000. Studies on the comparative yield potential of seven mungbean (Vigna radiata L.) genotypes. Pak. J. Biol. Sci., 3: 547-8

Anonymous. $2012 . \quad \mathrm{http}: / / \mathrm{www}$. aicrpmullarp.res.in/crop-profile. 619.

Anonymous. 2010-2011. pasted economics, Generic crop India IIPR English, Production and Productivity. Pulses Development Scheme, ZPD, Kanpur.

Anonymous. 2005-06. State Level Paradigm shift in planning needed. The Hindu Survey of Indian Agriculture, pp. 63

Anonymous. 2010-2011. Pasted economics, Generic crop India IIPR English, 
Production and Productivity. Pulses Development Scheme, ZPD, Kanpur.

Awomi, T. Alben., Singh, A.K., Kumar, Manoj and Bordoloi, L.J. 2012. Effect of phosphorus, molybdenum and cobalt nutrition on yield and quality of mungbean (Vignaradiata L.) in Acidic Soil of Northeast India. Indian J. Hill Farming, 25(2): 22-26.

Basak, R.K. and Sobodh, K. 2002. Efficiency of mixture of rock phosphate and super phosphate in green fodder maize pea crop sequence in alluvial soil. Environ. Ecol., 20: 894-896.

Carsky, R.J., Singh, B.B., and Oyewole, R. 2001. Contribution of early-season cowpea to late season maize in the savanna zone of West Africa. Biol. Agric. Hort., 18: 303-315.

Dixit, P.M. and Elamathi, S. 2007. Effect of foliar application of DAP, micronutrient and NAA on growth and yield of green gram (Vigna radiata L.). Legume Res., 30(4): 305-307.

Ganeshamurthy, A.N., C. Srinivasarao, Ali Masood and B.B. Singh. 2005. Balanced fertilization of greengram (Vigna radiata $\mathrm{L}$. Wilczek) cultivars on a multi-nutrient deficient typic Ustochrept soil. Indian $J$. Agri. Sci., 75(4): 192-196.

Giller, K.E., and Cadisch, G. 1995. Future benefits from biological nitrogen fixation: an ecological approach to agriculture. Plant Soil, 174: 255-27.

Gupta, B.R., Tiwari, R., Tiwari, T.P., and Tiwari, K.N. 2007. Maximizing yield, nutrient use Ahmad, R., M. Ikraam, E. Ullah and A. Mahmood (2003). Influence of different fertilizer levels on the growth and productivity of three green gram (Vigna radiata L. Wilczek) cultivars. Int. J. Agri. Biol., 05(3): 335-338, 2003.

Hemalatha, S.V., Shankaralingappa, B.C., Sudhir, K., Srinkanth, K. and Siddaramappa, R. 2002. Integrated phosphorus management for pigeon pea in an alfisol. Curr. Res. Univ. Agri. Sci., 31: 55-58.

Hussain, R., M. Imtiaz, G. Ahmad, M. Ramzan and G.A. Chaudhary. 1996. Response of mungbean to NP fertilizers under rainfed conditions of the Punjab. Pak. J. Soil Sci., 11: 95-8.
IIavarasi, K., Anuja, S., Shakila, A. and Angayakanni, A. 2007. Effect of phosphorus and potassium application on soil available NPK, their uptake and pod yield of cowpea [Vigna unguiculata (L.) Walp). Adv. Plant Sci., 20(1): 205-206.

Isherword, K.F. 1998. Fertilizer use and environment. In N. Ahmed and A. Hamid (eds.), Proc. Symp. Plant Nutrition Management for Sustainable Agricultural Growth (pp. 57-76.). NFDC, Islamabad.

Jena, D., Nayak, S.C., Mohanty, B., Jena Mukhi, S.K. 2009. Effect of boron and boron enriched organic manure on yield and quality of groundnut in boron deficient alfisol. Environ. Ecol., 237(2): 685-688.

Kumar, R.M., Subbaiah, S.V. and Surekha, K. 2002. Evaluation of murrorie rock phosphate as source of phosphorus in riceblack gram system. J. Res. ANGRAU, 30: 17.

Luikham, E., Lhungdim, J., Singh, A.I. 2005. Influences of sources and levels of phosphorus on growth and yield of greengram (Vigna radiata). Legume Res., 28(1): 59-61.

Malik, Amjad, Hassan, Fayyaz-Ul., Waheed, Abdul, Qadir, Ghulam and Asghar, Rehana. 2006. Interactive effects of irrigation and phosphorus on green gram (Vigna radiata L.). Pak. J. Bot., 38(4): 1119-1126.

Mondal, S.S., A. Ghosh. S. Biswajit, D. Acharya and B. Sarkar. 2003. Studies on the effect of potassium, sulphur and irrigation on growth and yield of greengram. $J$. Interacademicia, 7: 273-277.

Narendra Kumawat, Sharma, O.P. and Kumar, R. 2009. Effect of organic manures, PSB and phosphorus fertilization on yield and economics of mungbean (Vigna radiata L.) Wilczek. Environ. Ecol., 27(1): 5-7.

Prasad, S.K., Singh, M.K. and Singh, J. 2014. Response of rhizobium inoculation and phosphorus levels on mungbean (Vigna radiata L.) under guava-based agrihorti system. The Bioscan, 9(2): 557-560.

Rathi, B.K., Jain, A.K., Kumar, S., Panwar, J.D.S. 2009. Response of Rhizobium inocualtion with sulphur and micronutrient on yield and yield attributes of black gram (Vigna mung L. Hepper). Legume Res., 32(1): 62-64. 
Rathour, D.K., Gupta, A.K., Choudhary, R.R. and Sadhu, A.C. 2015. Effect of integrated phosphorus management on growth, yield attributes and yield of summer greengram (Vigna radiata L.). The Bioscan, 10(1): 0507.

Saha, A., B.K. Mandal and P. Mukhopadyay. 1996. Residual effect of boron and molybdenum on the yield of succeeding mungbean in summer. Indian Agriculturist, 40: 11-16.

Sharma, P. and Khurana, A.S. 1997. Biofertilizers, Farmers and Parliament, pp. 17-18.

Singh, A.K., R.K. Chaudhry and R.P.R. Sharma, 1993. Effect of inoculation and fertilizer levels on yield, nutrient uptake and economics of summer pulses. J. Potassium Res., 9: 176-8

Singh, M., H.S. Sekhon and J. Singh. 2005. Growth and nodulation characteristics of green gram (Vigna radiata L. Wilczek) geno types in response to phosphorus application. Crop Res., Hisar, 29(1): 101105.

Singh, R. and Tripathi, K.P. 2005. Productivity and economics of mung bean (Vigna radiata L. Wilczek) as influenced by varieties and nutrient management. J. Arid Legumes, 02(2): 223-226.

Suman, Dahama, A.K. and Poonia, B.L. 2007. Effect of balanced fertilization on growth and yield of greengram [Phaseolus radiates (L.) wilczek]. Haryana J. Agron., 23(1\&2): 118-119.

Tisdale, S.L., Nelson, W.L., Beaton, J.D. and Havlin, J.L. 2010. Soil fertility and fertilizer: An introduction to nutrient management. PHI Learning Pvt. Ltd., New Delhi. p. 184.

Yadav, R.S., Poonia, B.L. and Dahama, A.K. 2007. Effect of balanced fertilization on leaf area index, crop growth rate, relative growth rate, days to flower initiation and yield of green gram. Its proceeding at National symposium on legume for ecological sustainability, emerging challenges and opportunities, Nov 3-5, 2007 at Indian Institute of Pulse research, Kanpur.

Yakardi, M., Thatikunta, R. and Rao, L.M. 2002. Effect of nitrogen and phosphorus on growth and yield of greengram (Vigna radiata). Legume Res., 25(2): 139-141.

\section{How to cite this article:}

Preeti Choudhary, Gautam Ghosh, Neha and Shobha Kumari. 2017. Effect on Yield and Benefit Cost Ratio of Greengram at Different Phosphorus Levels and Frequency of Boron Levels. Int.J.Curr.Microbiol.App.Sci. 6(6): 1095-1103. doi: https://doi.org/10.20546/ijcmas.2017.606.127 